\title{
Serial verb constructions and their subtypes in Avatime
}

\author{
Rebecca Defina \\ Max Planck Institute for Psycholinguistics, International Max Planck \\ Research School for Language Sciences, Nijmegen
}

\section{Introduction}

This paper presents a description of Avatime serial verb constructions (SVCs), their properties, functions, and subtypes. Such a description is of wider typological interest due to Avatime's status as an agglutinating member of the Ghana-Togo Mountain branch of the otherwise typically isolating Kwa language family. It is also notable for the unusual system of truncated agreement markers and the distinction between nuclear and core SVC subtypes not typically reported for West African languages.

SVCs were first described among the Kwa languages Akan (Christaller 1875) and Ewe (Westermann 1907). Kwa languages have continued to feature prominently in SVC research since (e.g. Aboh 2009; Baker 1989; Bamgbose 1974; Collins 1997; Déchaine 1993; Lord 1993), particularly in the characterization of the West African serializing language type (Aikhenvald 2006; Ameka 2003; Dimmendaal 2001).

Ghana-Togo Mountain languages are a subgroup of Kwa noted for their typological differences (Heine 1968). These differences include a greater use of verbal morphology and, according to Dimmendaal (2001), a corresponding paucity of SVCs. However, more recent descriptions have reported frequently occurring SVCs (e.g. Ameka 2003, 2009; Bobuafor 2013; Dorvlo 2008; van Putten 2009) suggesting the reported lack of SVCs was due to the previously limited state of description. Nevertheless, Ghana-Togo Mountain languages are still mentioned relatively scarcely in discussions of SVCs and it is an open question how well they fit the West African serializing prototype based primarily on their isolating Kwa relatives. The present paper compares Avatime SVCs with those found in other, more prototypical, West African languages. In so doing, it finds many similarities but also many differences. Similarities are also noted between Avatime SVCs and 
those in other less typical West African serializing languages, such as Isu (Kießling 2011), as well as languages from further afield such as Oceania and East Asia.

\subsection{Defining serial verb constructions}

Before beginning the description of SVCs in Avatime, it is necessary to define what I mean by an SVC. Many definitions for SVCs have been proposed over the last decades (e.g. Aikhenvald 2006; Baker 1989; Collins 1997; Comrie 1995; Déchaine 1993; Durie 1997; Foley 1997; Foley \& Olson 1985; Lord 1993; Sebba 1987; Seuren 1991). Due to increasing evidence for variation among SVCs, there has been a shift towards identifying SVCs by resemblance to a prototype rather than by a list of strict necessary and sufficient conditions (Aikhenvald 2006; Durie 1997; Foley 2010; Senft 2008; van Staden \& Reesink 2008). This fits with a growing shift towards the use of many variables to identify prototypical or canonical constructions as in canonical typology (e.g. Brown, Chumakina, \& Corbett 2012). A good list of the properties believed to be prototypical of SVCs is provided by Durie (1997) and Aikhenvald (2006):

i. They consist of a sequence of two or more verbs which function independently as verbs in monoverbal clauses.

ii. They are monoclausal, with all the intonational properties of a monoverbal clause.

iii. There is one tense, aspect, mood and polarity value that is shared by all verbs. This is normally marked on one verb but is sometimes marked on all.

iv. There are no markers of subordination, coordination.

v. The verbs share at least one core argument.

vi. There is only one grammatical subject.

vii. The construction refers to a single event.

Two of these properties - intonation and referring to a single event - have been the subject of much theoretical concern (e.g. Bisang 2009; Crowley 2002; Foley 2010; Himmelmann 2013; Senft 2008). These concerns have often centred on how to determine whether or not a construction meets the criterion. However, I believe the issue is more basic and lies in the fact that neither intonation nor event structure are morpho-syntactic properties. Since SVCs are morpho-syntactic constructions, they should be identified solely by their morpho-syntactic properties. It is interesting to consider how intonation and event structures relate to morphosyntactic construction types such as SVCs, but for this to be done non-circularly they cannot be involved in the identification of these constructions. Constructions must first be defined for individual languages based on specific language internal morpho-syntactic criteria. Once there is a clearly defined construction type within 
a language, its properties can be compared with the typical cross-linguistic properties of various construction types and if there is a sufficiently good match it can be identified as an instance of that construction type. Only then may questions regarding how the construction relates to intonation or event structure be evaluated.

\subsection{Avatime background information}

Avatime, also called Siyase or Sidemese, is a member of the Ka subgroup of Ghana-Togo Mountain languages. Ghana-Togo Mountain languages are generally thought to be within the Kwa branch of Niger-Congo (Blench 2009; Heine 2008; Stewart 1989; Williamson \& Blench 2000), but whether the $\mathrm{Na}$ and Ka families together form a genetic unit and how they are related to the rest of the Kwa languages is still under debate (Blench 2009; Kropp Dakubu, in press)

Avatime is spoken by around 15,000 people in 7 villages in the Volta region of Ghana. Each village has its own subtly different dialect, mainly distinguished by phonological and lexical differences. There is not yet any evidence for syntactic variation across the dialects. The data reported here comes mostly from the village of Vane, though work was also conducted in Amedzofe, Biakpa, and Gbadzeme.

There are nine vowels $[i, \mathrm{I}\langle i \grave{i}\rangle, \mathrm{e}, \varepsilon, \mathrm{a}, \mathrm{J}, \mathrm{o}, \mathrm{v}\langle\mathrm{u}\rangle$, u] which participate in a system of advanced tongue root vowel harmony triggered by the stem (Maddieson 1998). Historically, there was most likely also an advanced tongue root variant of /a/ and the loss of this form has resulted in some idiosyncrasies, so that /e/ sometimes pairs with $/ \varepsilon /$ and sometimes with $/ a /$. The scope of vowel harmony is taken to indicate the boundaries of the word.

Avatime has three level tones: extra-high (marked '), high (unmarked) and low (marked '), for example tsyi 'turn', tsyi 'pour', tsyi 'tear'. The terms extra-high and high are used, rather than high and mid, since the extra-high tone has a restricted distribution, and is often the result of tone raising processes (see also van Putten 2014). Contour tones (marked ^ and ${ }^{\vee}$ ) occur rarely.

Like many other Ghana-Togo Mountain languages, Avatime is a noun class language of the Niger-Congo type. There are seven noun classes, six of which consist of singular and plural forms and one mass noun class (Schuh 1995). ${ }^{1}$ Noun classes are indicated by an obligatory noun class prefix on the noun root.

Verbs in Avatime are obligatorily marked with a prefix which simultaneously indicates subject agreement and one of six aspects or moods in paradigmatic

1. The noun classes are numbered $1-7$, which means each gender has its own number. This contrasts with the Bantu tradition where the pairings of singular and plural forms are often inconsistent and so each agreement pattern is given its own number. 
contrast: perfective, progressive, habitual, potential, subjunctive, and imperative. These prefixes were likely historically derived from the fusion of separate subject agreement and aspect or mood markers. The habitual is the only category which retains a separate marker $z \check{e}$ - $/ z \check{\varepsilon}$ - in addition to the agreement prefix and is thus doubly marked. There is no grammatical tense. Verbs can additionally be marked by two optional aspect/mood categories: the recurrent and the intentive. These occur in different slots on the verb and can be combined with the obligatory contrastive aspect and moods as well as each other. Negation is typically marked by a floating extra-high tone that attaches to the subject agreement prefix. When negating the subjunctive or imperative, a special prohibitive form is used instead of the standard negative. It is also possible to mark the verb with a directional prefix (itive or ventive) and a comitative suffix. The structure of the full Avatime verb complex is shown in (1). Example (2) shows a nearly fully saturated verb complex, lacking only the prohibitive. The comitative can still be seen at the end of the verb pani 'talk with someone', though the root $p a$ is no longer used independently. For more information regarding Avatime verbs and the tense, aspect, mood system see Defina (in press).

(1) Subject Agreement/Aspect/Mood - (Negative) - (Intentive) - (Recurrent) (Prohibitive) - (Directional) - Root - (Comitative)

(2) mó-tá-ž́-ž̌-panị=wo

1s.PFV.NEG-INT-REC-IT-talk.with $=2 \mathrm{~s} . \mathrm{OBJ}^{2}$

'I will not be going to talk with you.'

(Elicitation_081129_AB) ${ }^{3}$

Constituent order is strictly subject verb object as can be seen in example (3).

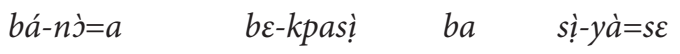

$\mathrm{C}_{1}$ p-person=DEF $\mathrm{C}_{1}$ p.PFV-learn $\mathrm{C}_{1}$ p.POS $\mathrm{C}_{7}$-language $=$ DEF

'The people learnt their (some other people's) language.'

(Avatime-history_110905_BB_037)

2. Abbreviations used: 1 'first person', 2 'second person', $C_{X}$ 'noun class $x$ ', см 'clause marker', СOM 'comitative', сомP 'complementizer', DEF 'definite', FOC 'focus', HAB 'habitual', IDEO 'ideophone', IMP 'imperative', INDEF 'indefinite', INF 'infinitive', INT 'intentive', IT 'itive', LOC 'locative', NMLZ 'nominalizing reduplication', NPREs 'non-present', OBJ 'object' p 'plural', PFV 'perfective', POS 'possessive', Рот 'potential', REC 'recurrent', REL 'relative clause marker', s 'singular', sBJ 'subject', sUBJ 'subjunctive', svm 'serial verb construction reduced agreement marker', vENT 'ventive'.

3. The source of each example is provided as (Text-Name_Date-Recorded(YYMMDD) Speaker's-Initials_Reference number in text transcription). No specific reference is given for sentences tested in multiple elicitation sessions unless the difference between consultants is relevant. The data is archived with The Language Archive. 
For further information regarding these and other aspects of Avatime grammar, the interested reader is directed to the grammar sketch in van Putten (2014) and the references therein.

The data used in this study come from a corpus of Avatime collected by van Putten and myself from 2008 till 2013. This corpus contains conversations, interviews, narratives, procedural texts, and elicited stories such as pear and frog stories. Wherever possible, examples are drawn from this corpus. Further data was gathered via elicitation sessions. Elicitation was especially valuable in probing the properties of particular SVCs, as discussed in Section 4. In these cases, all judgements were collected from between three and five consultants. Semantic properties were examined by testing implicatures and felicity judgements in particular contexts following a similar methodology as outlined by Matthewson (2004).

\section{Serial verb constructions in Avatime}

Avatime makes frequent use of a construction closely matching the crosslinguistic prototype for SVCs. The construction combines two or more verbs within a single clause, with no markers of subordination or coordination. The verb roots head independent phonological words, since they do not participate in vowel harmony. For instance, in example (4) the first verb has -ATR vowels while the second has +ATR and in example (5) the reverse pattern holds. The construction consists of a single clause since illocutionary force and negation necessarily scope over all verbs. The subject must be a shared argument of all verbs, and other arguments may optionally be shared. Two verbs - as in examples (4) and (5) - is the most common, and four verbs - as in example (6) - is the longest attested sequence.

(4) bị-lịla kú li-fu=nè

$\mathrm{C}_{4}$ P.PFV-vanish enter:LOC $\mathrm{C}_{3}$ s-sky=DEF

'They vanished into the sky.'

(Folktale_110406_QM_039)

(5) kっ be-bu=ye ple ke-sà

so $\mathrm{C}_{1}$ p.PFV-remove $=\mathrm{C}_{1}$ s.OBJ put.down $\mathrm{C}_{6}$ s-ground

'So they put him (the baby) down on the ground.'

(Midwifery_110901_AB_075)

(6) $a-k \dot{j}=b \varepsilon \quad$ nywa kpe kí $\quad$-ka-tsi=e

$\mathrm{C}_{1}$ s.PFV-take $=\mathrm{C}_{4}$ p.OBJ throw put give $\mathrm{C}_{1} \mathrm{~s}$-father-old $=$ DEF

'He threw it to the old man.'

The fact that these constructions consist of a single clause is sufficient to distinguish them from most other multiverbal constructions in Avatime. These tend 
to consist of multiple clauses where each verb is fully and independently inflected for subject, aspect, and mood and may also be independently marked for negation and illocutionary force, for example the causative in (7).

(7) $k \supset b \varepsilon-k i=w \supset \quad \quad w \supset-f_{\varepsilon}=s e=a \quad$ àló wo-dí

so $\mathrm{C}_{1}$ p.PFV-give $=2 \mathrm{~s}$.OBJ $2 \mathrm{~s} . \mathrm{PFV}$-lie=ground=DEF or $2 \mathrm{~s} . \mathrm{PFV}$-sit

'So they make you lie down or sit.' （Midwifery_110901_AB_025)

The only other constructions with multiple verbs in a single clause are the non-finite subordinate constructions. In these constructions, a verb - typically a phasal or modal verb such as kpese 'start' or tanị 'be able' - takes a non-finite verb phrase as a complement. The second verb can take one of three forms: bare verb stem (8a), prefixed with the non-finite marker $o-/ 0-(8 \mathrm{~b})$, or prefixed with the Class 5 singular noun class prefix $k u$-/ $k u$ - commonly used with deverbal nouns (8c). If the second verb takes an object it is fronted and occurs before the second verb.
a. e-kpese
$\grave{o}-n i=n \grave{o}$
to
$\mathrm{C}_{1}$ s.PFV-start $\mathrm{C}_{2} \mathrm{~s}$-soup $=$ DEF cook
'She started to cook the soup.'
b. e-kpese $\dot{o}-n i=n \dot{o} \quad$ - $t$ o
$\mathrm{C}_{1}$ s.PFV-start $\mathrm{C}_{2}$ s-soup=DEF INF-cook
'She started to cook the soup.'
c. e-kpese $\dot{o}$-ni=nò ku-to
$\mathrm{C}_{1}$ s.PFV-start $\mathrm{C}_{2}$ s-soup $=$ DEF $\mathrm{C}_{5}$ s-cook
'She started to cook the soup.'

There are no clear differences in usage between the three forms and even though the deverbal noun class is used in some cases, the verbs are not fully nominalized. In order to fully nominalise a verb the verb root must be reduplicated as in (9) where the nominalised verb functions as the subject of the clause.
ani $k u-m u \sim m u$
tsye ku-lí
$l \varepsilon=m \dot{\varepsilon}$
and $\mathrm{C}_{5} \mathrm{~s}$-NMLZ $\sim$ be.tall also $\mathrm{C}_{5}$ s.PFV-be.at $\mathrm{C}_{3} \mathrm{~s}=$ inside
'and there is drunkenness (lit. tallness) inside too.'

(Family-problems-task_110316_SO)

While the fully inflected first verb must be a single simple verb, the non-finite complement may consist of a complex predicate such as another non-finite subordinate construction, as in (10), or an SVC, as in (11).

èé-kpese tanì tì
$\mathrm{C}_{1}$ s.PROG-start be.able crawl

'He is starting to be able to crawl.' 


\section{(11) be-kpese $\quad b a-w a=t s \quad$ ts $\quad k u ́=w \varepsilon$ $\mathrm{C}_{1}$ p.PFV-start $\mathrm{C}_{5}$ p-medicine $=$ INDEF change give $=2 \mathrm{~s}$.OB $\mathrm{J}$}

'They start to change medicines for you.' (Midwifery_110901_AB_157)

There are formal and functional similarities between SVCs and non-finite subordinate constructions in Avatime: when the verb is not marked and there is no overt object, they look exactly like an SVC; and they are used for functions expressed using SVCs cross-linguistically (Aikhenvald 2006). Non-finite subordinate constructions and SVCs are, however, clearly distinct construction types in Avatime with different properties. The two verbs in non-finite subordinate constructions are always in a predicate argument relation and the first verb typically modifies the aspect or mood of the event described by the second verb. In contrast, the verbs in Avatime SVCs are never in a predicate argument relation (Haspelmath 2016). They are also distinguished by the different marking possibilities and position of the object for the subsequent verb. In the rest of this section, I describe the morpho-syntactic properties of Avatime SVCs in more detail with particular focus on the marking possibilities of subsequent verbs and argument sharing.

\subsection{Inflection within SVCs}

The first verb in an Avatime SVC is fully inflected for subject agreement, negation, aspect, and mood. Subsequent verbs are often not marked as in (4)-(6). They can also optionally be marked by a special reduced agreement prefix consisting of a single vowel and tone. These reduced agreement markers are only used with subsequent verbs in SVCs and are one of the features which distinguish SVCs from other multiverbal constructions in Avatime. I refer to them as serial verb markers (glossed as SVM).

If the SVC is in the perfective, then the serial verb markers are reduced forms of the normal subject agreement prefixes: the initial consonant, if any, is elided leaving the vowel and its associated tone, see examples (12)-(15) and Table 1. The use of agreement prefixes on subsequent verbs in SVCs is quite common among Ghana-Togo Mountain languages such as Likpe (Ameka 2003). The elision of the initial consonant of subject agreement prefixes in certain syntactic environments, often including SVCs, is also quite common among Ghana-Togo Mountain languages, e.g. Siwu (Kropp Dakubu \& Ford 1988) and Tafi (Bobuafor 2013). However, Avatime is the only one so far reported where these truncated subject agreement markers are restricted to subsequent verbs in SVCs. Outside of the Ghana-Togo Mountain languages, truncated subject agreement markers in SVCs have been reported in a few languages, such as Koṇḍa (Trans-New Guinea) and Bislama (Creole) (Aikhenvald 2006:41). 
(12)
a. $m \dot{e}-s e$
$\grave{e}-m u$
li-to=lè

1s.PFV-run SVM.1s.PFV-climb $\mathrm{C}_{3} \mathrm{~s}$-mountain=DEF

'I ran up the mountain.'
b. wò-se
$\dot{o}-m u$
$l i-t o=l \grave{~}$

2s.PFV-run SVM.2s.PFV-climb $\mathrm{C}_{3} \mathrm{~s}$-mountain=DEF

'You ran up the mountain.'
c. ki-se
i-mu
$l i-t o=l e ̀$

1p.PFV-run svM.1p.PFV-climb $\mathrm{C}_{3} \mathrm{~s}$-mountain=DEF

'We ran up the mountain.'

(13) rrrrrr

$$
\text { be-tre } \quad \boldsymbol{e}-m u
$$

IDEO:continuously $\mathbf{C}_{1}$ p.PFV-go svM.c ${ }_{1}$ p.PFV-climb

'They were going up for a long time.' (Avatime-history_110905_BB_018)

(14) nite $m \dot{e}$ sị $k a-p \grave{a}=t s$

LOC:like.that inside COMP $\mathrm{C}_{6} \mathrm{~s}-\mathrm{part}=\mathrm{INDEF}$

ke-mu li-to=lè abù

$\mathbf{C}_{6}$ s.PFV-climb SVM.C 6 s.PFV-enter $\mathrm{C}_{3}$ s-mountain=DEF top

'In that way one group climbed onto the mountain.'

(Avatime-history_110905_BB_125)

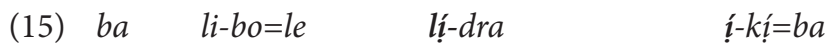

$\mathrm{C}_{1}$ p.SBJ $\mathrm{C}_{3}$ s-matter $=$ DEF $\mathrm{C}_{3}$ s.PFV.NEG-be.clear $\mathbf{s V M}$. $\mathrm{C}_{3}$ S.PFV.NEG-give $=\mathrm{C}_{1}$ p.OBJ

'As for them, the matter is not clear for them.' (Folkstory_110406_QM_086)

Table 1. Subject agreement prefixes in SVCs in the perfective. Pairs refer to vowel harmony pairs. Prefixes with consistently low and extra-high tones are marked. The tone of other prefixes varies with the tone of the verb root as well as the tone of the antecedent's noun class prefix.

\begin{tabular}{|c|c|c|c|c|}
\hline & \multicolumn{2}{|l|}{ Positive } & \multicolumn{2}{|l|}{ Negative } \\
\hline & Full & SVM & Full & SVM \\
\hline $1 \mathrm{~s}$ & me-/ma- & e-/a- & mó-/mó- & ó-/’́- \\
\hline $1 \mathrm{p}$ & ki-/kị- & i-/ị- & kú-/kụ́- & ú-/ứ- \\
\hline $2 \mathrm{~s}$ & wo-/wo- & $0-/ 0-$ & wó-/wó- & ó-/ó- \\
\hline $2 \mathrm{p}$ & $\mathrm{mle}-/ \mathrm{mle}-$ & $\mathrm{e}-/ \varepsilon-$ & mlá- & á- \\
\hline $\mathrm{C}_{1} \mathrm{~S}$ & e-/a- & e-/a- & ó-/’́- & ó-/j́- \\
\hline $\mathrm{C}_{1} \mathrm{p}$ & be-/be- & $\mathrm{e}-/ \varepsilon-$ & á- & á- \\
\hline $\mathrm{C}_{2} \mathrm{~S}$ & è-/ $/ \grave{\varepsilon}-$ & è-/ & ó-/ว́- & ó-/ó- \\
\hline $\mathrm{C}_{2} \mathrm{p}$ & ì-/ị- & ì-/ị- & í-/ị́- & í-/ị́- \\
\hline $\mathrm{C}_{3} \mathrm{~S}$ & li-/lị- & i-/ị- & lí-/lị́- & í-/ị́- \\
\hline
\end{tabular}


Table 1. (continued)

\begin{tabular}{|c|c|c|c|c|}
\hline & \multicolumn{2}{|l|}{ Positive } & \multicolumn{2}{|l|}{ Negative } \\
\hline & Full & SVM & Full & SVM \\
\hline $\mathrm{C}_{3} \mathrm{p}$ & $\mathrm{e}-/ \varepsilon-$ & $\mathrm{e}-/ \varepsilon^{-}$ & á- & á- \\
\hline $\mathrm{C}_{4} \mathrm{~S}$ & ki-/ki- & i-/ị- & kí-/kị́- & í-/ị́- \\
\hline $\mathrm{C}_{4} \mathrm{p}$ & bi-/bị- & i-/ị- & bí-/bị́- & í-/ị́- \\
\hline $\mathrm{C}_{5} \mathrm{~S}$ & ki-/kị- & i-/ị- & kú-/kụ́- & ú-/ụ́- \\
\hline $\mathrm{C}_{5} \mathrm{p}$ & be-/be- & $\mathrm{e}-/ \varepsilon-$ & bá- & á- \\
\hline $\mathrm{C}_{6} \mathrm{~s}$ & ke-/ke- & $\mathrm{e}-/ \varepsilon-$ & ká- & á- \\
\hline $\mathrm{C}_{6} \mathrm{p}$ & ki-/kị- & i-/ị- & kú-/kụ́- & ú-/ụ́- \\
\hline $\mathrm{C}_{7}$ & si-/sị- & i-/ị- & sí-/sị́- & í-/ị́- \\
\hline
\end{tabular}

If the SVC is not in the perfective, the serial verb marker has a fixed form and does not agree with the subject. If the SVC is in the potential mood, the serial verb

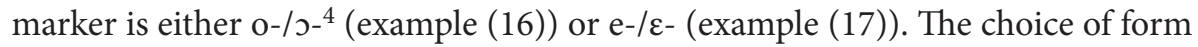
varies between speakers. Individuals are very consistent in which form they use and the variation does not seem important to Avatime speakers, nor does it correlate with any obvious factors such as dialect, gender, or age.

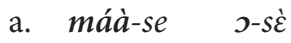
1s.POT-run svm.Pот-leave
'I will run away.'

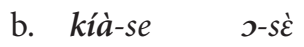
1р.Pот-run svm.Рот-leave
'We will run away.'

(Elicitation_100719_AB)

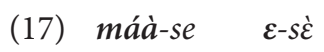

1s.POT-run svм.Pot-leave

'I will run away.'

(Elicitation_100714_QM)

In other aspects and moods, the form of the serial verb marker is é-/र́-, for instance, in the progressive in (18a) and (19), and the habitual in (18b) and (20). Example (21) shows é-/ź- is also used in the negative.

a. wèć-gà $\dot{\varepsilon}-z a$

2s.PROG-walk SVM.PROG-pass

'You are passing through.'

4. This has the same form as one of the prefixes used with subordinate verbs in the non-finite constructions. While this may indicate some relationship between the two, there is also a large amount of homophony within the svm paradigm and so this particular instance of homophony does not provide any strong motivation for assuming such a relationship. 


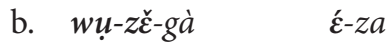

2s.HAB-HAB-walk SVM.HAB-pass

'You pass through (all the time).

(19) ḃé-ywya $\quad \dot{\varepsilon}-k p \varepsilon$

C 1 p.PROG-throw SVM.PROG-put.in

'They were throwing (it) in'.

(20) nite mè sị ba petee bị́-ž̀-za

LOC:like.that inside COMP C ${ }_{1}$ p.sBJ all C $_{1}$ p.HАB-HAB-pass

ć-klanị $\quad \dot{\varepsilon}-p \varepsilon \quad b i ̣-\eta \dot{a} \sim \eta \dot{a}=w \varepsilon$

SVM.HAB-go.around SVM.HAB-want $\mathrm{C}_{4} \mathrm{p}-\mathrm{NMLZ} \sim$ eat $=\mathrm{DEF}$

ní $l i$-ywàfụ $=n \varepsilon \quad m \dot{\varepsilon}$

LOC $\mathrm{C}_{3} \mathrm{~s}$-forest=DEF inside

'So they all used to roam around the forest looking for food.'

(Folkstory_110406_QM_033)

(21) kù-ni=o kú-lí-kpe é-ple

$\mathrm{C}_{5} \mathrm{~s}$-water $=$ DEF $\mathbf{C}_{5}$ s.PROG.NEG-PROG.NEG-put.in SVM.PROG-descend

'The water doesn't flow (in the river).' (Avatime-history_110905_BB_087)

The optional recurrent aspect and intentive mood modifiers do not influence the serial verb markers. For instance, the serial verb markers in examples (22) and (23) are truncated forms of the subject agreement prefixes as would typically be found in the perfective, rather than the 5 - or $\dot{\varepsilon}$ - forms found with the other contrastive aspects and moods.
$y \varepsilon ́$
sị $\quad b \varepsilon-t a ́-k j$
$\varepsilon-w a ̀$
kunu=yè
$\mathrm{C}_{1}$ s:FOC.SBJ COMP $\mathrm{C}_{1}$ p.PFV-INT-take sVM.C ${ }_{1}$ p.PFV-use funeral=DEF

'He is the one they will use for the funeral.' (Folkstory_110406_QM_124)
$a-z \check{\varepsilon}-s e$
$a-\operatorname{tr\varepsilon }$
ní jvanj

$\mathrm{C}_{1}$ s.PFV-REC-run SVM.C ${ }_{1}$ s.PFV-go LOC Vane

'He was running to Vane.'

As mentioned at the beginning of this section, use of the serial verb markers is optional and has no apparent semantic or pragmatic influence. The frequency of their use varies according to age. Older speakers use them very frequently, and younger speakers use them only rarely, if at all. This suggests they may be lost in future generations and that the apparent optionality is linked with this shift in the language rather than having an independent functional motivation. 


\subsection{Aspect and mood within SVCs}

Typically, all verbs in an SVC must share a single value for aspect and mood (Aikhenvald 2006; Durie 1997). This restriction is, however, reported to be relaxed among Kwa languages where it is common for each verb phrase to be individually modifiable for aspect and modality (Ameka 2003). In particular, the local lingua franca Ewe (Ameka 2006) and Avatime's close relative Tafi (Bobuafor 2013:302) both allow independent marking of aspect and modality on each verb within an SVC as long as it is semantically plausible. One could, thus, expect Avatime to follow the local pattern and allow independent marking of aspect and modality within SVCs. However, that is not the case. Avatime has six contrastive aspects and moods: perfective, progressive, habitual, potential, subjunctive, and imperative (Defina, in press). All simple monoverbal clauses must be marked for one and only one of these categories. The situation is the same for SVCs.

The markers for all six contrastive aspects and moods have historically fused with the subject agreement prefixes so that both categories are now indicated using the one agreement prefix as can be seen in examples (24)-(29).

(24) be-sị níklo $\varepsilon-p \dot{\varepsilon} \quad k i ́=b a$

$\mathrm{C}_{1}$ p.PFV-say there $\mathrm{C}_{2}$ S.PFV-be.good give $=\mathrm{C}_{1}$ p.oBJ

'They said as for that place, it was good for them.'

(Avatime-history_110905_BB_139)

(25) kì- $d z i \quad$ tre $k \grave{e}-d e=a$ tàe

1p.PROG-return go $\mathrm{C}_{6}$ s-back=DEF a.little

'We are going back a little.'

(Midwifery_110901_AB_132)

(26)

$b a ́-n \grave{j}=a t s \quad b e-z \grave{e} \quad g i ̀ \quad b a \quad k o ́ n$

$\mathrm{C}_{1}$ p-person=INDEF $\mathrm{C}_{1}$ p.PFV-be.NPRES REL $\mathrm{C}_{1}$ p.sBJ at.all

bị́-ž̀-po kị $\quad b a ́-n j=a$

$\mathrm{C}_{1}$ p.HAB-HAB-help give $\mathrm{C}_{1}$ p-person=DEF

'There were special people who used to help people (deliver babies)'

(Midwifery_110901_AB_012)

(27) bíà-ko manị be-bi=wà

$\mathrm{C}_{1}$ p.POT-take bring $\mathrm{C}_{1}$ p.POS-child $=\mathrm{DEF}$

'They will bring (it) to their children.'

(Folktale_110406_QM_013)

(28) kっ bí-zizi wo ke-le=a mè petee $k i ́=w \jmath=\varepsilon$

so $\mathrm{C}_{1}$ p.suBJ-spoil 2 s.POS $\mathrm{C}_{6} \mathrm{~s}$-world $=$ DEF inside all give $=2 \mathrm{~s} . \mathrm{OBJ}=\mathrm{CM}$

'So they'll spoil all your life for you.'

(Midwifery_110901_AB_140) 
(29)

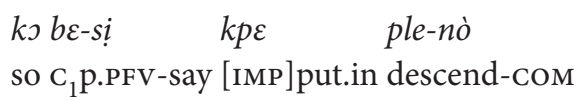

'So they said "push down!".

(Midwifery_110901_AB_026)

The habitual is the only form which has a separate marker (example (26)), but even here the $z \check{e}$-/ž্ - prefix is not sufficient for indicating the aspect since it is homophonous with the recurrent and itive prefixes and thus requires the agreement prefix for disambiguation. In the case of the imperative (example (29)), the mood is marked by the absence of the agreement prefix. This fusion of aspect and mood marking with subject agreement makes it impossible to use the standard strategies for marking aspect and mood in monoverbal clauses with subsequent verbs in SVCs.

It is also not considered grammatical to use a serial verb marker to indicate an aspect or mood different to that of the first verb, as can be seen in example (30). Example (a) attempts to combine a perfective marked first verb with a potential marked serial verb marker. Example (b) attempts to combine a perfective marked first verb with the $\dot{\varepsilon}$ - serial verb marker which can indicate progressive, habitual, or subjunctive. Habitual would not be semantically plausible in this case, but progressive and subjunctive should be with an interpretation such as 'You left Gbadzeme and are coming to Vane' or 'You left Gbadzeme to come to Vane' respectively. Example (c) attempts to combine a potential marked first verb with a perfective serial verb marker on the second verb. All three sentences are regarded as ungrammatical.
a. ${ }^{*} m l \varepsilon-d s$
Gbàdzemè o-ba
ว̀vanว̀
2p.PFV-move.from Gbadzeme svM.POT-come Vane
b. ${ }^{*} m l \varepsilon-d o$
Gbàdzemè $\dot{\varepsilon}-b a$
Òvanว̀
2p.PFV-move.from Gbadzeme svM.Prog/subJ-come Vane
c. * kịà-do
Gbàdzemè ị-ba
J̀vanว̀
1p.PoT-move.from Gbadzeme svm.1p.PFV-come Vane

(Elicitation_100717_AB)

It is thus not possible to independently mark verbs within Avatime SVCs for aspect or mood categories from this contrastive set. However, Avatime also has two optional categories: the recurrent and intentive. These can be additionally marked on any simple monoclausal verb and since they are marked by independent morphemes, they do not face the same practical limitations as the other aspects and moods.

The recurrent aspect, used for indicating repeated action, can in fact modify each part of an SVC independently. For instance, the (a) examples in (31) and (32) have the recurrent marked on the first verb $d z \varepsilon$ 'go' and the going is necessarily 
repeated, while the (b) examples have the recurrent marked on the second verb wà 'work' and it is only the working and not the going which is repeated.

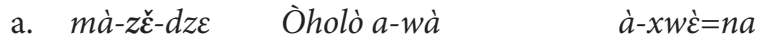
1s.PFV-REC-go Ho svM.1s.PFV-work $\mathrm{C}_{3}$ p-job=DEF
'I was going to Ho and working.' (went and returned repeatedly)

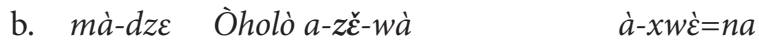
1s.PFV-go Ho svm.1s.PFV-REC-work $\mathrm{C}_{3}$ p-job=DEF
'I went to Ho and was working.' (moved there for sometime)

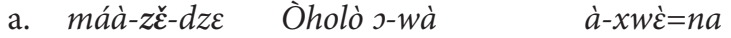
1s.POT-REC-go Ho SVM.POT-work $\mathrm{C}_{3}$ p-job=DEF
'I will be going to Ho and working.' (coming and going repeatedly)
1s.POT-go Ho SVM.POT-REC-work $\mathrm{C}_{3} \mathrm{p}$-job=DEF
'I will go to Ho and be working.' (move there for sometime)

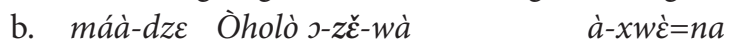

This is only possible with some SVCs, such as those expressing sequential action (See Section 4). For example, according to speaker reports, the SVC in (33) must describe separate consecutive actions of making and giving rather than the benefactive interpretation of making rice for the people.
mà-tó kị-mịmị kpáù a-ž̌-kí
$b a ́-n \dot{\jmath}=a$
1s.PFV-cook $\mathrm{C}_{4}$ s-rice plenty sVM.1s.PFV-REC-give $\mathrm{C}_{1}$ p-person=DEF
'I made plenty of rice and was giving it to the people.'

In the case of the intentive mood, however, there appears to be a more fundamental restriction. The intentive marker tá- can only occur on the first verb of an SVC and it must scope over the whole construction, as shown in the following examples. Example (34a) shows an SVC with the first verb marked with the intentive. Discussions with consultants showed the intentive does not narrowly apply to the first verb $k j$ 'take' since the sentence can also be used when the speaker has picked up the axe but not (yet) used it for splitting the firewood. Example (34b) shows it is not possible to specify this interpretation by marking the intentive on the second verb. This can only be done using two separate clauses as in (34c).
a. ma-tá-kj
$k \grave{a}-w \mathcal{\varepsilon}=a \quad a-y \grave{a} i$
$\dot{j}-n y \dot{i}=n \dot{\jmath}$
1s.PFV-INT-take $\mathrm{C}_{6}$ s-axe=DEF SVM.1s.PFV-break $\mathrm{C}_{2}$ s-firewood=DEF
'I intend to split the firewood with the axe'/'I intend to take the axe and split the firewood.' (can be used regardless of whether or not the speaker is already holding the axe) 
b. ${ }^{*} m a-k j \quad k \grave{j}-w \varepsilon=a \quad a-t a ́-y a ̀ i \quad j-n y i=n j$

1s.PFV-take $\mathrm{C}_{6} \mathrm{~s}$-axe=DEF SVM.1s.PFV-INT-break $\mathrm{C}_{2} \mathrm{~s}$-firewood=DEF Intended: 'I took the axe and intend(ed) to split the firewood.' or 'I intend(ed) to split the firewood with the axe (which I am already holding)'.

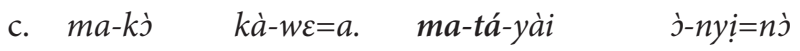
1s.PFV-take $\mathrm{C}_{6} \mathrm{~s}$-axe=DEF 1s.PFV-INT-break $\mathrm{C}_{2} \mathrm{~s}$-firewood=DEF 'I took the axe. I intend(ed) to split the firewood.'

This restriction even holds with SVCs more clearly referring to sequential actions, as demonstrated by example (35). The sentence in (a) shows a sequential action SVC with the intentive marked on the first verb and scoping over both actions. Example (b) shows it is still not possible to mark the intentive on the second verb to give a narrow scope reading. This can again only be achieved by using separate clauses as in ( $c$ and $d)$.
a. $\quad m a ̀-t a ́-d z \varepsilon$
Òholò $a-w a ̀ ~$
$\grave{a}-x w \grave{\varepsilon}=n a$
1s.PFV-INT-go Ho svM.1s.PFV-work $\mathrm{C}_{3} \mathrm{p}$-job=DEF
'I intend to go to Ho and work.'

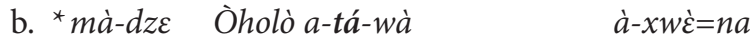
1s.PFV-go Ho sVM.1s.PFV-INT-work $\mathrm{C}_{3} \mathrm{p}$-job=DEF
Intended: 'I went to Ho intending to work.'
c. $m a ̀-d z \varepsilon$ Òholò ma-tá-wà à-xwè=na
1s.PFV-go Ho 1s.PFV-INT-work $\mathrm{C}_{3}$ p-job=DEF
'I went to Ho and intend to work.'
d. mà-dze Òholò to máà-wà à-xwè=na
1s.PFV-go Ho PURP 1s.POT-work $\mathrm{C}_{3}$ p-job=DEF
'I went to Ho in order to work.'

\subsection{Argument sharing within SVCs}

The verbs in Avatime SVCs share a single grammatical subject. This subject must also be the actor argument for all verbs in the SVC, as in (36).
(36) $l \check{\varepsilon} \quad b e-d z i$
$m u=i$
then $\mathrm{C}_{1}$ p.PFV-return ascend $=\mathrm{CM}$
'Then they ascended again.'

(Avatime-history_110905_BB_019)

This means Avatime does not allow the sort of switch subject resultative SVCs commonly found in many other serializing languages, where the second verb is intransitive and takes the undergoer of the first verb as its sole argument (37). These sorts of resultative meanings may, however, be expressed using SVCs in Avatime 
if the second verb is transitive, as in (38), or labile, as in (39), so the subject of the first verb is the actor for both verbs. A similar restriction is also reported in Ewe and another Ghana-Togo Mountain language Likpe (Ameka 2003).

(37) ${ }^{*} a-t a \quad o-g a=\varepsilon \quad$ tse

$\mathrm{C}_{1}$ s.PFV-shoot $\mathrm{C}_{1}$ s-goat=DEF die

Intended: 'He shot the goat dead.'

(38)

$a-t a \quad \quad-g a=\varepsilon \quad y e$

$\mathrm{C}_{1}$ S.PFV-shoot $\mathrm{C}_{1} \mathrm{~s}$-goat=DEF kill

'He shot the goat dead.'

(39) a. wò-trutru ò-pupo=lò dra

2s.PFV-push $\mathrm{C}_{2}$ s-door=DEF open

'You pushed the door open.'

b. w'̀-dra $\dot{o}$-pupo=lò

2s.PFV-open $\mathrm{C}_{2} \mathrm{~s}$-door $=\mathrm{DEF}$

'You opened the door.'

c. $\dot{o}$-pupo=lò $\quad \dot{\varepsilon}-d r a$

$\mathrm{C}_{2} \mathrm{~s}$-door $=$ DEF $\mathrm{C}_{2}$ S.PFV-open

'The door is open.'

Other arguments may also be shared by the verbs within an SVC. In these cases, they are mentioned once only with their first verb. For instance, in example (40) the object of the first verb (lififline 'a type of porridge') is shared by the subsequent three verbs in the SVC.

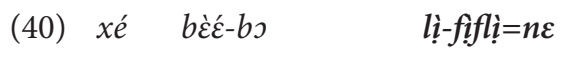

when $\mathrm{C}_{1}$ p.PROG-mould $\mathrm{C}_{3} \mathrm{~s}$-type.of.porridge $=\mathrm{DEF}$

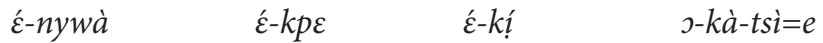

SVM.PROG-throw SVM.PROG-put SVM.PROG-give $\mathrm{C}_{1} \mathrm{~s}$-father-old=DEF

'When they were molding the porridge and threw it to the old man.'

(Folktale_110406_QM_069)

\subsection{Focus and SVCs}

As is common for West African SVCs (Ameka 2003), individual verbs in Avatime SVCs can be marked for focus. Most commonly, focus is marked on the first verb. This can have narrow scope over that particular verb, as in (41). Here speaker A asks a question consisting of two clauses, the first has focus on the verb gà 'walk' the second clause contains an SVC with 'run' and 'go'. Speaker B responds with a single SVC clause with focus on the first verb. 
(41)
A: ki-gá
afua a-gà
aló e-se
$\operatorname{tr\varepsilon }$

VFOC-walk:FOC Afua $\mathrm{C}_{1}$ S.PFV-walk or $\mathrm{C}_{1}$ S.PFV-run go

ní kè-dzi=à $m \grave{\varepsilon} \quad n a$ ?

LOC $\mathrm{C}_{6} \mathrm{~s}$-market=DEF inside QM

'Did Afua walk or run to the market?'

B: ki-sé e-se tre

VFOC-run:FOC $\mathrm{C}_{1}$ S.PFV-run go

'She $[\mathrm{ran}]_{\mathrm{FOC}}$ to the market.'

Alternatively, it can have broad scope over the whole SVC or even relate more to the second verb, as in (42), where the important point is really the leaving rather than the getting up.

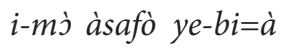

$$
\begin{aligned}
& \text { ki-yó } \\
& \text { be-yó } \\
& \text { sé lo }
\end{aligned}
$$

'Look at Asafo's children, they [got up and left $]_{\text {Foc' }}$ (Conv-street_100720-2)

It is also possible for non-initial verbs to be focused, as in (43). This appears to be much less common and so far is only attested in elicitation sessions after prompting.
$k i-n u ́$
ग-nùv $\dot{\jmath}^{\prime}=y \varepsilon \quad o-d i$
$n u \quad b \supset l=y \varepsilon$
VFOC-listen:FOC $\mathrm{C}_{1} \mathrm{~s}$-child=DEF $\mathrm{C}_{1}$ s.PFV-sit listen football=DEF
'The boy sat $[\text { listening }]_{\mathrm{Foc}}$ to the football.'

\subsection{Summary of Avatime SVC properties}

Avatime SVCs are characterized by the following properties:

i. A sequence of two or more verbs in a single clause

ii. No predicate-argument relation between the verbs

iii. Only the first verb is fully inflected for subject agreement, aspect, mood, and polarity

iv. Subsequent verbs may be bare or prefixed with a reduced agreement marker

v. The recurrent aspect may be independently marked on subsequent verbs in some SVCs, all other aspects and moods may be marked only once on the first verb and scope over the whole construction.

vi. The subject must be an argument of all verbs

vii. Other arguments may also be shared by verbs within the SVC, in which case they are mentioned once only following their first verb.

viii. Individual verbs may be focused

Avatime SVCs thus exhibit many properties typical of West African serial constructions. In particular, their ability to focus individual verbs, the lack of switch 
subject resultative type SVCs, and the ability to independently mark subsequent verbs for aspect. They also differ from the typical West African pattern in their use of reduced agreement markers on subsequent verbs and the more generally typical restrictions on independent aspect and mood marking. In the next section, I examine the different functions SVCs are utilized for in Avatime.

\section{Semantic functions of Avatime SVCs}

Avatime SVCs are employed for a broad range of semantic functions. These functions can be divided into three broad groups: modifying, argument adding or marking, and grouping consecutive actions. These semantic groupings also have subtly different syntactic properties as discussed further in Section 4.

In modifying SVCs, the first verb modifies the way the action described by the second verb is performed. These include the typical manner plus path of motion SVCs, as in (44) where the first verb describes the manner and the second the path.

$$
\text { kò e-se do níls gì } e \text {-kpò=e }
$$

then $\mathrm{C}_{1}$ S.PFV-move.quickly move.from there REL $\mathrm{C}_{1}$ S.PFV-hide $=\mathrm{CM}$

'Then he ran out from where he was hiding.' （Folktale_110406_QM_076)

Another kind of modifying SVC is where the first verb describes the posture of the actor during the action or state described by the second verb, as in (45).

$$
\begin{aligned}
& o-d i \quad \eta w \dot{\varepsilon} \\
& \mathrm{C}_{1} \text { s.PFV-sit drink } \\
& \text { 'S/he sits drinking.' }
\end{aligned}
$$

I also include among the modification SVCs some slightly less typical cases, such as when two path verbs combine in an SVC to create a complex path, as in (46) and (47). Note in these cases the two path elements combine simultaneously with the first verb modifying the way in the motion described by the second verb is carried out. They thus fall within the modifying SVC category rather than the sequential category discussed below.

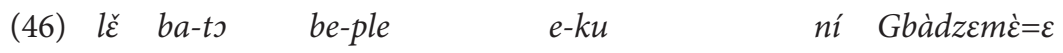
and $\mathrm{C}_{1}$ p-INDEF $\mathrm{C}_{1}$ p.PFV-descend SVM.C ${ }_{1}$ p.PFV-enter LOC Gbadzeme $=\mathrm{CM}$ 'And some descended into Gbadzeme.' (Avatime-history_110905_BB_129)

(47) $l \check{\varepsilon} \quad b e-d z i \quad m u=i$ and $\mathrm{C}_{1}$ p.PFV-return ascend $=\mathrm{CM}$ 'Then they ascended again.' (Avatime-history_110905_BB_019) 
Finally, I also include SVCs such as (39), repeated here as (48), and (49) within the modification type of SVCs. In these SVCs, the first verb is an activity verb describing the manner of achieving the action described by the second verb. They are often translated using a resultative construction. However, since the second verb is transitive, they have more in common with the manner plus path SVCs than with resultative SVCs in many other languages where the result is generally expressed by an intransitive stative verb.

(48) wo-trutru ò-pupo=lò dra

2s.PFV-push $\mathrm{C}_{2}$ s-door=DEF open

'You pushed the door open.'

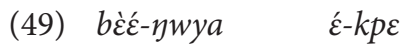

$\mathrm{C}_{1}$ p.PROG-throw SVM.PROG-put.in

'They were throwing (it) in.'

(Folktale_110406_QM_033)

The second major type of semantic function for Avatime SVCs is argument adding or marking. There are two types of argument adding SVCs. In both, the choice of verb is fixed and the construction is moving towards grammaticalization. One type is formed with the 'give' verb $k i$ as the second verb and is used to add a benefactor or recipient role, as in (50).

(50)
$b \varepsilon-p l \varepsilon$
$j$-tosì $=l o$
$\varepsilon-k !^{5}$
$\grave{o}-k u s i=e$
$\mathrm{C}_{1}$ p.PFV-put.down $\mathrm{C}_{2} \mathrm{~s}$-bed.mat=DEF svM.C $\mathrm{C}_{1}$ p.PFV-give $\mathrm{C}_{1} \mathrm{~s}$-chief $=\mathrm{DEF}$

'They laid a bed for the chief.'

(Avatime-history_110905_BB_114)

The other type uses the 'take' verb $k j$ as the first verb and adds an instrument, means, or manner, as in (51)-(53) respectively.

$\begin{array}{lll}a-k \grave{j} & k \grave{a}-w \mathcal{E}=a \quad y a ̀ i & \grave{o}-s e=l \grave{o} \\ \mathrm{C}_{1} \mathrm{~S} \cdot \mathrm{PFV}-\text { take } \mathrm{C}_{6} \mathrm{~s} \text {-axe }=\text { DEF break } \mathrm{C}_{2} \mathrm{~s} \text {-tree }=\mathrm{DEF}\end{array}$

'He used an axe to split the tree.'

(52) $a-k \dot{j}$

$k u-z \dot{o} \quad d z i \quad$ ohonete

$\mathrm{C}_{1}$ s.PFV-take $\mathrm{C}_{5} \mathrm{~s}$-theft become rich.person

'Through theft he became a rich man.'

(53)
$a-k \dot{j} \quad k u$-siyeyome sì
$\mathrm{C}_{1}$ S.PFV-take $\mathrm{C}_{5} \mathrm{~s}$-anger leave
'He left in anger.'

5. Note the tone on the 'give' verb $k i$ is raised from high to extra-high. This is done whenever 'give' is used as a non-initial verb in an SVC regardless of whether it has a benefactive function, as is the case here, or its full literal meaning as in example (54). 
In addition to adding a new argument, 'take' verbs can be used to mark the theme in a three-place predicate, as in (54). Note the theme argument is already an argument of the second verb; it is not added by the take verb, as shown in (54b). Such object marking is a very common function of take-SVCs crosslinguistically, both within and outside West Africa (Lord, 1993).

$$
\begin{aligned}
& \text { a. } a-k \dot{j} \quad l i-b a=l \varepsilon \quad k i ́=y \varepsilon \\
& \mathrm{C}_{1} \text { s.PFV-take } \mathrm{C}_{3} \mathrm{~s}-\mathrm{hoe}=\mathrm{DEF} \text { give }=\mathrm{C}_{1} \mathrm{~s} \text {.OBJ } \\
& \text { 'He gave him the hoe.' } \\
& \text { b. } a-k i=y \varepsilon \quad l i-b a=l \varepsilon \\
& \mathrm{C}_{1} \text { s.PFV-give }=\mathrm{C}_{1} \text { s.OBJ } \mathrm{C}_{3} \mathrm{~s}-\mathrm{hoe}=\mathrm{DEF}
\end{aligned}
$$

The 'take' verbs used to introduce new arguments are more semantically bleached and grammaticalized than the 'take' verbs used to mark themes in threeplace predicates. When introducing new arguments, only the generic $k j$ 'take' verb can be used. In contrast, when marking a theme any of the verbs of taking can be used depending on the kind of object and how it was taken, as can be seen in (55) where the 'gather' verb is used with the theme rice.

$$
\begin{aligned}
& \text { kobe-halì } \quad a \text {-mu=nà } \quad \varepsilon \text {-manj̀ } \\
& \text { so } \mathrm{C}_{1} \text { p.PFV-gather } \mathrm{C}_{3} \text { p-rice= }=\text { DEF SVM.C }{ }_{1} \text { p.PFV-bring } \\
& \text { ní ke-tsripà mì ní j̀-nyo=nj } m \dot{\varepsilon} \\
& \text { LOC } \mathrm{C}_{6} \mathrm{~s} \text {-clearing inside LOC } \mathrm{C}_{2} \mathrm{~s} \text {-farm=DEF inside } \\
& \text { 'They brought the rice to the clearing in the farm.' }
\end{aligned}
$$

(Rice-farming_100613_EN_066)

The final function of Avatime SVCs is to combine consecutive actions, as in (56). These sequential actions must form a single culturally relevant and cohesive unit, generally with an overarching goal. For instance, the source and goal of a motion event, as in (57), or the actions required for achieving a task such as cooking a meal, as in (58). When there is no such overarching goal, the actions can only be combined using coordinated sentences, as in (59). This restriction is a common property of sequential action SVCs and has been noted by several researchers for other languages (e.g. Bruce 1988; Diller 2006; Durie 1997; Enfield 2002; Jarkey 1991; Lewis 1993).

$$
\begin{aligned}
& l \check{\varepsilon} \quad a-y a=l \varepsilon \quad e-d \grave{u}=i \\
& \text { then } \mathrm{C}_{1} \text { s.PFV-divide }=\mathrm{C}_{3} \text { s.OBJ sVM. } \mathrm{C}_{1} \text { s.PFV-put }=\mathrm{CM} \\
& \text { 'Then she divided it (the porridge) and put it down.' }
\end{aligned}
$$

(Folktale_110406_QM_029) 
(57)

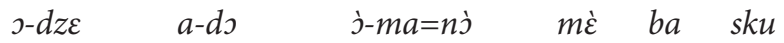
$\mathrm{C}_{1}$ s-woman $\mathrm{C}_{1}$ s.PFV-exit $\mathrm{C}_{2} \mathrm{~s}$-town=DEF inside come school 'The woman left the town and came to school.'
ma-tsà tomatoes $=y e \quad a-k p \varepsilon$
ní $k \grave{e}-z i=a$
$m \dot{\varepsilon}$

1s.PFV-cut tomatoes $=$ DEF SVM.1s.PFV-put LOC $\mathrm{C}_{6} \mathrm{~s}$-bowl=DEF inside

'I cut tomatoes and put them in the bowl.'

a. ${ }^{*} m a$-tsà tomatoes=ye $a$-sé $k e-p e=a \quad m \dot{\varepsilon}$ 1s.PFV-cut tomatoes $=$ DEF SVM.1s.PFV-leave:LOC $\mathrm{C}_{6}$ s-house $=$ DEF inside Intended: 'I cut tomatoes and left the house.'

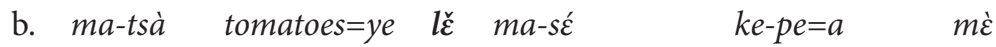
$1 \mathrm{~s} . \mathrm{PFV}$-cut tomatoes $=\mathrm{DEF}$ and $1 \mathrm{~s} . \mathrm{PFV}$-leave:LOC $\mathrm{C}_{6} \mathrm{~s}$-house $=\mathrm{DEF}$ inside 'I cut tomatoes and left the house.'

\section{Subtypes of SVCs in Avatime}

The SVCs used for the different types of functions - modifying, argument marking and adding, and combining sequential actions - have subtly different morpho-syntactic properties. These differences divide Avatime SVCs into three subtypes - nuclear, core, and sequential - which to a large extent, but not exactly, mirror the functional divisions, see Tables 2 and 3.

I discuss each of the subtypes in detail below. I use the Role and Reference Grammar (RRG) analysis of SVCs (Foley \& Olson 1985; Foley \& Van Valin 1984; Van Valin 2005) as a helpful way of describing the data, since it closely matches the observed Avatime patterns. Thus, I shall briefly introduce the essential aspects of RRG before continuing with the description of SVC subtypes in Avatime. There are two main ideas behind the RRG analysis of complex clauses: nexus types and the layered structure of the clause (Van Valin \& Foley 1980; Van Valin 2005). There are three nexus types, or ways of joining elements together. These are the standard subordination and coordination, and an additional type called cosubordination, which combines coordination like properties with the operator dependence

Table 2. Semantic functions of SVCs in each subtype

\begin{tabular}{ll}
\hline Subtype & Semantic functions \\
\hline Nuclear & $\begin{array}{l}\text { Modifying (Posture, Manner+path, Complex path, and Manner+activity) } \\
\text { Theme marking }\end{array}$ \\
Core & $\begin{array}{l}\text { Argument adding and theme marking } \\
\text { Modifying (Manner+activity) }\end{array}$ \\
Sequential & Combining consecutive actions \\
\hline
\end{tabular}


Table 3. Properties of Avatime SVC subtypes

\begin{tabular}{lllll}
\hline Property & & Nuclear & Core & Sequential \\
\hline Can aspectual adverbials & between verbs? & Marginally & Yes & Yes \\
occur & with restricted scope? & No & Yes & Yes \\
Can directionals occur & on subsequent verbs? & Marginally & Yes & Yes \\
& with restricted scope? & No & Not clear & Yes \\
Can the recurrent occur & on subsequent verbs? & No & Yes & Yes \\
& with restricted scope? & No & Not clear & Yes \\
Can locational or temporal & between verbs? & No & Yes & Yes \\
adverbials occur & with restricted scope? & No & No & Yes \\
\hline
\end{tabular}

typical of subordination (Van Valin 2005:187). RRG also divides clauses into a layered structure of three parts (see Figure 1). The nucleus is the bare predicate and in a simple clause would consist of the verb stem only. The core consists of the predicate plus any core arguments. The periphery contains any non-core arguments, such as adjuncts. The nucleus is contained within the core, the periphery is adjoined to the core, and all together they make up the clause. These nexus types and parts of the clause interact to form different kinds of complex clauses, for instance two nuclear level units can be joined via subordination or coordination, or coordination could be used to connect two periphery level units.

CLAUSE

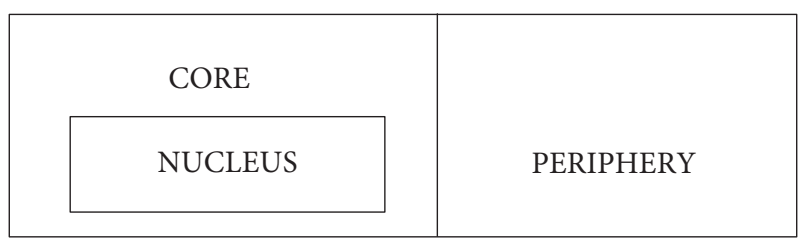

Figure 1. The RRG layered structure of the clause (adapted from Van Valin 2005:4)

In nuclear SVCs, the verbs are joined together, via cosubordination, under a single nucleus node. This is a tight bond and the verbs in these SVCs cannot be modified individually by nuclear level operators, such as aspectual modifiers. Core SVCs, in contrast, contain two separate nuclear nodes each within separate core nodes which are joined, via cosubordination, under another core node. The verbs in these SVCs can have their own distinct core arguments and be individually modified by nuclear, but not core, level operators (Foley \& Olson 1985). 


\subsection{Nuclear SVCs in Avatime}

The core members of this group are SVCs where the first verb modifies the way the action described by the subsequent verb is carried out i.e. manner, posture, or complex path. Additionally, SVCs where a 'take' verb marks the theme argument of a three-place predicate sometimes behave like these modifying SVCs though they may also behave like the argument adding SVCs discussed in the next section. This variation does not mean they have some traits of nuclear and some traits of core SVCs. Rather a speaker sometimes responds to all questions consistently as if the construction behaves like the modifying SVCs and other times responds as if it behaves in the same way as the argument adding SVCs.

Nuclear SVCs are the most restrictive, with the tightest connection between their verbs. The verbs cannot be independently modified and adverbials do not typically appear between them. Directional affixes can occur on one verb only, typically the first, and always scope over the whole construction, as can be seen in (60) and (61). ${ }^{6}$ In these two examples, the SVCs in (a) have a first verb marked with a directional which scopes over the whole construction. The SVCs in (b) show the dispreference for placing a directional on the second verb: the itive in (60) was rejected by all consultants, while the ventive in (61) was rejected by two out of three consultants.

(60)
a. Komla a-ze-tà
$\jmath-g \grave{a}=\varepsilon$ ye
Komla $\mathrm{C}_{1}$ s.PFV-IT-shoot $\mathrm{C}_{1}$ s-goat=DEF kill
'Komla went and killed the goat.'
b. ${ }^{*}$ Komla a-tà
ग-gà $=\varepsilon$
$z e-y e$
Komla $\mathrm{C}_{1}$ s.PFV-shoot $\mathrm{C}_{1} \mathrm{~s}$-goat=DEF IT-kill
Intended: 'Komla went and killed the goat.'
a. Komla a-bá-kj

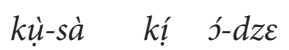
Komla $\mathrm{C}_{1}$ s.PFV-VENT-take $\mathrm{C}_{5}$ s-cloth give $\mathrm{C}_{1}$ s-woman
'Komla came and gave the cloth to the woman.'

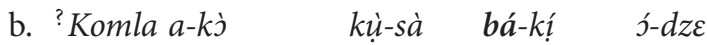
Komla $\mathrm{C}_{1}$ s.PFV-take $\mathrm{C}_{5}$ s-cloth VENT-give $\mathrm{C}_{1}$ s-woman
'Komla came and gave the cloth to the woman.'

\footnotetext{
6. Asterisks indicate that all informants consistently rejected the sentence. Question marks indicate that most consultants rejected the sentence as ungrammatical but at least one speaker at one time accepted it. Other sentences were accepted by all informants. All sentences were tested with between three and five consultants.
} 
The recurrent aspect - the only aspect that can independently modify verbs within some Avatime SVCs (Section 2.2) - can only be marked on the first verb in nuclear SVCs, as in (62).
a. $\quad b a-z \check{\varepsilon}-d \underline{n}$
$\eta w \grave{\varepsilon} \quad k \grave{u}-g o ̀ d a$
$\mathrm{C}_{1}$ p.PFV-REC-sit drink $\mathrm{C}_{6}$ s-palmwine
'They were sitting drinking palmwine.'
b. ${ }^{\star} b a-d i ́ \quad z \check{\varepsilon}-\eta w \dot{\varepsilon} \quad k \grave{u}$-gòda
$\mathrm{C}_{1}$ p.PFV-sit REC-drink $\mathrm{C}_{6}$ s-palmwine

Aspectual adverbials between the verbs are strongly dispreferred according to speaker judgements and regardless of position always scope over the entire construction, as can be seen in (63).
(63) a. koko ba-dí gu ku-nugu=yò
already $\mathrm{C}_{1}$ p.PFV-sit talk $\mathrm{C}_{5}$ s-mouth $=\mathrm{DEF}$
'They already sat talking.'
b. ba-dị gu ku-nugu=yò koko
$\mathrm{C}_{1}$ p.PFV-sit talk $\mathrm{C}_{5} \mathrm{~s}$-mouth= DEF already
'They already sat talking.'
c. ?ba-dí koko gu ku-nugu=yò
$\mathrm{C}_{1}$ p.PFV-sit already talk $\mathrm{C}_{5} \mathrm{~s}$-mouth $=\mathrm{DEF}$
'They already sat talking.'

While aspectual adverbials are dispreferred between the verbs, they are occasionally accepted in that position (63c). In contrast, locative and temporal adverbials are never accepted between the verbs, for instance (64) and (65). In all cases the adverbial scopes over the whole SVC.

(64)
a. me-feke

$$
l i \grave{-k l a}=n \dot{\varepsilon}
$$
vù níyà
1s.PFV-pick.up $\mathrm{C}_{3} \mathrm{~s}$-stone $=$ DEF hold here
'I picked up the stone here.'
b. * me-feke
$l i-k l a=n \dot{\varepsilon}$
níyà vù
1s.PFV-pick.up $\mathrm{C}_{3}$ s-stone $=$ DEF here hold

Intended: 'I picked up the stone here held it.'

(65) a. ba-dí gu ku-nugu=yò kivòe $\mathrm{C}_{1}$ p.PFV-sit talk $\mathrm{C}_{5}$ s-mouth=DEF yesterday

'They sat talking yesterday.'
b. ${ }^{*} b a-d i$
kivòe $\quad g u \quad k u$-nugu=yò
$\mathrm{C}_{1}$ p.PFV-sit yesterday talk $\mathrm{C}_{5}$ s-mouth=DEF
Intended: 'They sat yesterday talking.' 
The fact that aspect and directionals must scope over both verb phrases suggests the verbs are within a single nucleus in RRG terms (Van Valin 2005). In the early days of RRG, it was believed nuclear SVCs would also require the verbs to be adjacent with no intervening object noun phrase (Foley \& Olson 1985). However, several languages have since been documented where nuclear SVCs allow object NPs to occur between the verbs (Bril 2004; Crowley 2002; Durie 1997). Avatime is the first example of this within West Africa, a region which was previously claimed to lack nuclear SVCs due to the believed adjacency restriction (Foley \& Olson 1985).

\subsection{Core SVCs in Avatime}

The principle members of this group are argument-adding SVCs. Additionally, SVCs with a 'take' verb used to mark a theme argument and the manner plus action type of modifying SVCs can also occur in this group. Avatime core SVCs typically allow subsequent verbs to be independently modified. Adverbials can occur between the verbs, though locational and temporal adverbials scope over the whole construction.

Subsequent verbs in core SVCs can be marked with directionals. This is shown in example (66) where consultants reported a difference in meaning between the sentences in (a) and (b). Placing the directional on the second verb in (b) gives the construction more of a sequential action rather than a purely instrumental reading. Given the semantics of the directional, a narrow scope reading would automatically lead to a sequential action interpretation. It is not clear whether a narrow scope use of the directional shifts the SVC over to the sequential subtype (Section 4.3). Further testing with locational and temporal adverbials would be needed to discriminate these two possibilities. It is, however, notable that narrow scope use of the directionals is not possible with nuclear SVCs even though such a shift in interpretation would be semantically plausible.
a. $m a-z \mathcal{E}-k \dot{j} \quad k \grave{a}-w \mathcal{E}=a \quad t s \grave{o} \grave{o}-s e=l \grave{o}$
1s.PFV-IT-take $\mathrm{C}_{6} \mathrm{~s}$-axe $=$ DEF cut $\mathrm{C}_{2} \mathrm{~s}$-tree $=$ DEF
'I went and used the axe to cut the tree.'
b. $m a-k \dot{j} \quad k \grave{a}-w \mathcal{E}=a \quad z \mathcal{E}-t s \grave{a} \dot{o}-s e=l \grave{o}$
1s.PFV-take $\mathrm{C}_{6} \mathrm{~s}$-axe $=$ DEF IT-cut $\mathrm{C}_{2} \mathrm{~s}$-tree $=$ DEF
'I took the axe to go cut the tree.'

The recurrent aspect can be placed on subsequent verbs in core SVCs. When it is used with benefactive SVCs, a sequential action reading is given, as in (67). When it is used with instrumentative SVCs, the recurrent can have narrow scope without leading to a sequential action meaning, as in (68). In (68b) the cutting of 
the tree is what is repeated. The axe was used for at least some of this time, but may have only been one of the tools used. Whereas in (68a), it is the axe using that is repeated.

(67) mà-to kị-mịmị kpáùn ž̌-kị bá-nj̀=a 1s.PFV-cook $\mathrm{C}_{4}$ s-rice plenty REC-give $\mathrm{C}_{1}$ p-person=DEF 'I made plenty of rice and was giving it to people.'
a. $a-z \check{\varepsilon}-k \dot{j}$
$k \grave{a}-w \mathcal{\varepsilon}=a$
tsà $\grave{o}-s e=l \grave{o}$
$\mathrm{C}_{1}$ S.PFV-REC-take $\mathrm{C}_{6} \mathrm{~s}$-axe $=$ DEF cut $\mathrm{C}_{2} \mathrm{~s}$-tree $=$ DEF
'He was using the axe to cut the tree.'
b. $a-k \dot{j} \quad k \grave{a}-w \mathcal{\varepsilon}=a \quad z \grave{\varepsilon}-t s \grave{a} \quad \dot{o}-s e=l \grave{o}$
$\mathrm{C}_{1}$ S.PFV-take $\mathrm{C}_{6} \mathrm{~s}$-axe $=$ DEF REC-cut $\mathrm{C}_{2} \mathrm{~s}$-tree $=$ DEF
'He used the axe and was cutting the tree.'

Aspectual adverbials can easily occur between verbs in these SVCs and can have restricted scope over one verb phrase only, as can be seen in (69). Here the adverb koko 'already' modifies the first verb phrase ebu àgbèliye idrulè 'he dug cassava mounds', but does not scope over the second verb phrase kị Kwami 'give to Kwami' which may be yet to occur.
$e-b u$

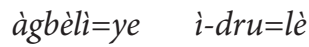
kóko kị Kwami
$\mathrm{C}_{1}$ s.PFV-remove cassava $=\mathrm{DEF} \mathrm{C}_{2} \mathrm{p}$-mound= $\mathrm{DEF}$ already give Kwami

'He already dug cassava mounds for Kwami.' (i.e. the cassava mounds have been dug, possibly without the intention of giving them over to Kwami.')

Locative and temporal adverbials can also occur between verbs in core SVCs. Unlike aspectual adverbials, they must scope over the entire SVC unless they modify one of the nominal arguments. So the pairs of SVCs in (70) and (71) have the same meaning, though the locational adverbial in (71b) can also be interpreted as modifying the nominal 'cloth' rather than the action.
a. mà-dzE Òholò kị Akosua kivòe
1s.PFV-go Ho give Akosua yesterday
'I went to Ho for Akosua yesterday.'
b. mà-dzE Òholò kivòe kí Akosua 1s.PFV-go Ho yesterday give Akosua 'I went to Ho for Akosua yesterday.'
a. $a-k j$
$k \grave{u}-s \grave{a}=a$
$k i ́ \quad j-d z \varepsilon=\varepsilon$
$\mathrm{C}_{1}$ s.PFV-take $\mathrm{C}_{5} \mathrm{~s}$-cloth $=$ DEF give $\mathrm{C}_{1} \mathrm{~s}-$ woman $=\mathrm{DEF}$
ní $k e-p e=a$
$m \dot{\varepsilon}$
LOC $\mathrm{C}_{6}$ s-house $=$ DEF inside
'He gave the cloth to the woman in the house.' 
b. a-kj̀ kị̀-sà=a ní $k e-p e=a \quad m \grave{\varepsilon}$

$\mathrm{C}_{1}$ s.PFV-take $\mathrm{C}_{5} \mathrm{~s}$-cloth $=$ DEF LOC $\mathrm{C}_{6}$ s-house $=$ DEF inside

$k i ́$ j- $d z \varepsilon=\varepsilon$

give $\mathrm{C}_{1} \mathrm{~s}$-woman $=\mathrm{DEF}$

'He gave the cloth to the woman in the house.'/ 'He gave the cloth in the house to the woman.'

It is also not considered grammatical to have two locative or temporal adverbials within a single core SVC. For instance in example (72), the first SVC in (a) with two temporal adverbials is considered ungrammatical. In the case of the SVC in (b) with two locational adverbials, the first adverbial phrase must refer to the location of the object rather than the location of the taking action.
a. ${ }^{*} a-k j$
$k \grave{u}-s \grave{a}=a$
kivòe
$k i ̣ \quad j-d z \varepsilon=\varepsilon$
òmonò
$\mathrm{C}_{1}$ s.PFV-take $\mathrm{C}_{5}$ s-cloth=DEF yesterday give $\mathrm{C}_{1} \mathrm{~s}$-woman $=$ DEF today
b. $a-k j$
$k \grave{u}-s \grave{a}=a$
ní $k e-p e=a$
$m \dot{\varepsilon}$
$\mathrm{C}_{1}$ s.PFV-take $\mathrm{C}_{5}$ s-cloth=DEF LOC $\mathrm{C}_{6}$ s-house $=$ DEF inside

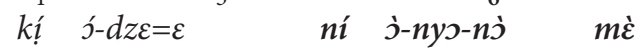
give $\mathrm{C}_{1} \mathrm{~s}$-woman=DEF LOC $\mathrm{C}_{2} \mathrm{~s}$-farm=DEF inside
'He gave the cloth (which is) in the house to the woman on the farm.'

In an RRG analysis, the fact that aspect can be independently marked in each verb phrase shows they form separate nuclei. Since there can be only one locational or temporal modifier, there is only one periphery. This combination suggests these SVCs are formed via core cosubordination.

\subsection{Sequential SVCs in Avatime}

SVCs combining sequential actions constitute the most semantically and morphosyntactically divergent group in Avatime. They are the only SVCs which can be paraphrased with coordinated sentences, for instance (73) and (74).
a. $m a \dot{a}-d 0$
$G b a ̀ d z \varepsilon m \grave{\varepsilon} \grave{a}-b a$
J̀vaǹ̀
1s.PFV-move.from Gbadzeme svM.1s.PFV-come Vane
'I left Gbadzeme came to Vane.'
b. mà-do
Gbàdzemè ľ̌ mà-ba
ગ̀vanò
1s.PFV-move.from Gbadzeme and 1s.PFV-come Vane
'I left Gbadzeme and came to Vane.'

(74)
a. ma-tsà tomatoes=ye $a-k p \varepsilon$
ní $\quad k \dot{e}-z i=a$
$m \grave{\varepsilon}$
1s.PFV-cut tomatoes=DEF SVM.1s.PFV-put LOC $\mathrm{C}_{6}$ s-bowl=DEF inside 'I cut tomatoes and put them in the bowl.' 


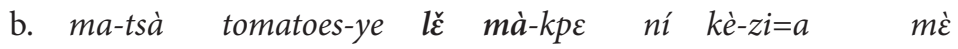
1s.PFV-cut tomatoes-DEF and 1s.PFV-put LOC $\mathrm{C}_{6} \mathrm{~s}$-bowl=DEF inside 'I cut the tomatoes and put them in the bowl.'

It is also possible to modify each verb phrase in a sequential SVC with different temporal or locational adverbials, as in (75).
a. mà-do Gbàdzcmè kivòe à-ba
1s.PFV-move.from Gbadzeme yesterday svm.1s.PFV-come
j̀vanj̀ òmonò
Vane today
'I left Gbadzeme yesterday and came to Vane today'.
b. ma-tsà tomatoes=ye ní $l i ̣-v l \varepsilon=l \grave{\varepsilon}$
1 s.PFV-cut tomatoes $=$ DEF LOC $\mathbf{C}_{3}$ s-morning $=$ DEF
$a-k p \varepsilon \quad n i ́$ kè-zi=a mì áblà

sVM.1s.PFV-put LOC $\mathrm{C}_{6} \mathrm{~s}$-bowl=DEF inside now

'I cut the tomatoes in the morning and put them in the bowl now.'

This is not possible with other types of SVCs. So the separate adverbials in (76) force a sequential rather than an instrumental interpretation.
a. $a-k \dot{j}$
$k \grave{a}-w \varepsilon=a \quad n i ́ \quad k e-p e=a$
$m \dot{\varepsilon}$
$\mathrm{C}_{1}$ s.PFV-take $\mathrm{C}_{6} \mathrm{~s}$-axe $=$ DEF LOC $\mathrm{C}_{6} \mathrm{~s}$-house $=$ DEF inside

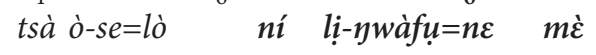
cut $\mathrm{C}_{2} \mathrm{~s}$-tree $=$ DEF LOC $\mathrm{C}_{3} \mathrm{~s}$-forest $=$ DEF inside
'He took the axe from inside the house, and cut the tree in the forest.'
Not: 'He used the axe (taken from inside the house) to cut the tree in the forest'

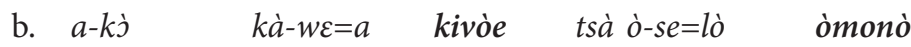
$\mathrm{C}_{1}$ s.PFV-take $\mathrm{C}_{6} \mathrm{~s}$-axe=DEF yesterday cut $\mathrm{C}_{2} \mathrm{~s}$-tree $=$ DEF today
'He took the axe yesterday, cut the tree today'.
Not 'He used the axe yesterday, cut the tree today'.

In terms of RRG, the fact that each verb can be modified by a locational or temporal modifier suggests sequential SVCs are formed by core coordination rather than cosubordination. In core coordination, each verb has its own periphery which allows them to be individually modified by locational and temporal modifiers, yet both verbs still share clause level markers such as mood (Van Valin 2005).

This property also means Avatime sequential SVCs do not have the macroevent property. Bohnemeyer and colleagues (2007) introduced the macro-event property as a way of evaluating whether constructions refer to single macro-events or not. A construction has the macro-event property if temporal operators necessarily scope over the entire construction (Bohnemeyer et al. 2007:497). SVCs are 
typically claimed to refer to single macro-events (e.g. Aikhenvald 2006; Comrie 1995; Durie 1997). Indeed in many West African languages there are other morpho-syntactic differences between constructions which allow independent modification by temporal and locational adverbials and SVCs which do not (Ameka 2003). This is not the case in Avatime where some SVCs do not have the macroevent property. Bisang (2009) suggested just such a possibility when he suggested some action sequences may allow independent modification by temporal adverbials but still refer to culturally determined event units and be described using SVCs. This appears to be the case in Avatime, where SVCs can only join action sequences which are understood by Avatime speakers to form coherent units (Section 3).

\subsection{Avatime SVC subtypes discussion}

The distinction between the sequential and other SVCs in Avatime is an example of a type of division commonly made within serialising languages. This type of division is known by many different names, such as symmetrical versus asymmetrical (Aikhenvald 2006), with different terms often being used for different languages or language groups. For instance, linking versus modifying has been used with West African languages (Bamgbose 1974), chaining versus integrated more specifically with Akan (Hellan, Beermann \& Andenes 2003; Osam 1994), and narrative versus compact has mainly been used with Austronesian and Papuan languages (Pawley 2008; van Staden \& Reesink 2008). The different terms have also been defined in different ways. Symmetrical SVCs are defined as those where all verbs come from open classes and have equal status in the construction (Aikhenvald 2006:22). Linking and chaining SVCs are defined as those which can be derived from (Bamgbose 1974: 18) or paraphrased by (Osam 1994:195) coordinated clauses. Narrative SVCs are defined as those expressing a sequence of loosely integrated events (Pawley 2008: 174) where the verbs can be independently modified by locational and temporal modifiers (Pawley 2008: 174; van Staden \& Reesink 2008: 30). All these properties co-occur in Avatime sequential SVCs. Indeed, there appears to be a common idea behind all of these distinctions, separating the more coordinate-like SVCs used for combining sequential actions from the more modifying type SVCs and the clustering of these properties has been noted before in other languages (e.g. Pawley 2008).

The nuclear versus core SVC distinction is commonly discussed in descriptions of Austronesian and Papuan languages (e.g. van Staden \& Reesink 2008) but not West African languages. When Foley and Olson (1985) introduced the distinction, they claimed it would not be relevant for most West African languages excepting the verb final languages Ijọ and Igbo. More recent work on Austronesian languages has shown nuclear SVCs do in fact occur in verb medial languages with 
objects occurring between the verbs (e.g. Bril 2004; Crowley 2002; Durie 1997). Despite this discovery, the relevance of the distinction has not been reconsidered for West African languages. The distinction between nuclear and core subtypes in Avatime is subtle. While it is not typical for the two types to be distinguished so subtly, it has been reported. For instance, in the Austronesian language Taba, where the main implication of the nuclear versus core SVC distinction is how it affects verbal animacy restrictions (Bowden 2008). It is possible the nuclear versus core distinction will turn out to be relevant for more West African languages, and may even help explain some of the differences noted among SVCs within some languages, for instance the differences in subject marking in Akan SVCs (Ameka 2003; Osam 1994). Indeed, a critical reading of Kießling's (2011) description of SVCs in Isu (West-Ring, Grassfields, Niger-Congo) suggests they may also be divided into nuclear and core subtypes.

The differences between the Avatime SVC subtypes are only observable in some conditions, such as when certain modifiers are used. This is not an unusual situation and has also been noted in other languages, for instance the situation in Avatime is quite similar to that of the SVC subtypes in Lao (Enfield 2007). It does, however, mean the subtypes cannot be used functionally by Avatime speakers to modify the meaning of a construction. Instead, the pairing of functions with subtypes is typically fixed with particular functions only being expressed using SVCs of a single type. This is especially true for the sequential SVCs. The nuclear and core subtypes have more functional overlap. Each subtype has its principle members (Table 2): modifying SVCs all appear in the nuclear subtype and argument adding SVCs are core SVCs. Other functions, such as 'take' SVCs used to mark themes and manner plus action SVCs, can occur in either type. These kinds of SVCs do not behave like nuclear SVCs in some ways and core SVCs in others. Rather, speakers appear to select one type or the other and then respond to all questions in a way consistent with that type. The two subtypes are thus distinct with some functions appearing in both types rather than forming a middle point on a cline. These cases where certain functions can be performed by SVCs of different types suggest the distinctions between the subtypes are not solely due to the semantics.

\section{Conclusion}

Avatime lies in the heart of the Kwa serialising area of West Africa, but it is also one of the Ghana-Togo Mountain languages known for their typological divergence from the surrounding Kwa languages. The description presented here shows Avatime SVCs conform to the West African type (Ameka 2003) in many ways. For 
instance, the subject must be a shared argument of all verbs and individual verbs can be marked for focus within the SVC. However, there are also ways in which Avatime SVCs are more like those from further afield. For instance, the reduced subject agreement markers have closer parallels in serialising languages outside rather than inside the West African region. The characteristics of the subtypes also have much in common with subtypes described among Austronesian, Papuan, and South-East Asian serialising languages and the literature on those languages helps inform an analysis of Avatime. This description of Avatime SVCs thus contributes to a better understanding of the range of variation within West African SVCs and also the possible similarities and connections between SVCs in different linguistic areas.

\section{Acknowledgements}

Firstly, I am grateful to the Avatime people for their support and assistance. The ideas here were first presented at the 43rd Colloquium on African Languages and Linguistics in Leiden 2013. Many thanks for the discussion and comments received there. This paper also greatly benefitted from discussions with Robert D. Van Valin, thank you. Also many thanks to Felix Ameka, Julija Baranova, Thomas Bearth, Gabriella Garrido, Rósa Gísladóttir, Stephen C. Levinson, Asifa Majid, Saskia van Putten, Gunter Senft, Ewelina Wnuk, and two anonymous reviewers for commenting on earlier versions of the paper. This work was supported by the Max Planck Gesellschaft.

\section{References}

Aboh, E. O. 2009. Clause structure and verb series. Linguistic Inquiry 40(1). 1-33. doi: 10.1162/ling.2009.40.1.1

Aikhenvald, A. Y. 2006. Serial verb constructions in typological perspective. In A. Y. Aikhenvald \& R. M. W. Dixon (eds.), Serial verb constructions: A cross-linguistic typology, 1-68. Oxford: Oxford University Press.

Ameka, F. K. 2003. Multiverb constructions in a West African areal typological perspective. In Proceedings of TROSS 3. Retrieved from http://edvarda.hf.ntnu.no/ling/tross/TROSS03toc.html

Ameka, F. K. 2006. Ewe serial verb constructions in their grammatical context. In A. Y. Aikhenvald \& R. M. Dixon (eds.), Serial verb constructions: A cross-linguistic typology, 124143. Oxford: Oxford University Press.

Ameka, F. K. 2009. Likpe. In G. J. Dimmendaal (ed.), Coding participant marking: Construction types in twelve African languages, 239-280. Amsterdam: John Benjamins. doi:10.1075/slcs.110.11ame

Baker, M. C. 1989. Object sharing and projection in serial verb constructions. Linguistic Inquiry 20(4). 513-553. 
Bamgbose, A. 1974. On serial verbs and verbal status. Journal of West African Languages 9(1). $17-48$.

Bisang, W. 2009. Serial verb constructions. Language and Linguistics Compass 3(3). 792-814. doi: 10.1111/j.1749-818X.2009.00128.x

Blench, R. 2009. Do the Ghana-Togo mountain languages constitute a genetic group? Journal of West African Languages 36(1\&2). 19-36.

Bobuafor, M. 2013. A grammar of Tafi. Leiden: Leiden University Ph.D. dissertation.

Bohnemeyer, J., N. J. Enfield, J. Essegbey, I. Ibarretxe-Antuñano, S. Kita, F. Lüpke \& F. K. Ameka. 2007. Principles of event segmentation in language: The case of motion events. Language 83(3). 495-532. doi:10.1353/lan.2007.0116

Bowden, J. 2008. Verb serialisation in Taba. In G. Senft (ed.), Serial verb constructions in Austronesian and Papuan languages, 75-98. Canberra: Pacific Linguistics.

Bril, I. 2004. Complex nuclei in Oceanic languages: Contribution to an areal typology. In I. Bril \& F. Ozanne-Rivierre (eds.), Complex predicates in Oceanic language: Studies in the dynamics of binding and boundness, 1-48. Berlin: Mouton de Gruyter. doi: 10.1515/9783110913286.1

Brown, D., M. Chumakina \& G. G. Corbett (eds.). 2012. Canonical morphology and syntax. Oxford: Oxford University Press. doi:10.1093/acprof:0so/9780199604326.001.0001

Bruce, L. 1988. Serialisation: from syntax to lexicon. Studies in Language 12. 19-49. doi:10.1075/sl.12.1.03bru

Christaller, J. G. 1875. A grammar of the Asante and Fante language called Tshi (Chwee, Twi). Basel: Basel German Evangelical Mission. Reprinted in 1964 by Gregg Press Inc., Ridgewood, N.J.

Collins, C. 1997. Argument sharing in serial verb constructions. Linguistic Inquiry 28(3). 461497.

Comrie, B. 1995. Serial verbs in Haruai (Papua New Guinea) and their theoretical implications. In J. Bouscaren, J. Franckel \& S. Robert (eds.), Langues et langage: Problèmes et raisonnement en linguistique, mélanges offerts à Antoine Culioli, 25-37. Paris: University Presses of France.

Crowley, T. T. 2002. Serial verbs in Oceanic: A descriptive typology. Oxford: Oxford University Press. doi:10.1093/acprof:0so/9780198241355.001.0001

Déchaine, R.-M. 1993. Serial verb constructions. In J. Jacobs, A. von Stechow, W. Sternefeld \& T. Vennemann (eds.), Syntax: An international handbook of contempory research, vol. 1, 799-825. Berlin, New York: Walter de Gruyter.

Defina, R. In press. Tense, aspect and mood in Avatime. Afrika Und Uberzee.

Diller, A. V. N. 2006. Thai serial verbs: Cohesion and culture. In A. Y. Aikhenvald \& R. M. W. Dixon (eds.), Serial verb constructions: A cross-linguistic typology, 160-177. Oxford: Oxford University Press.

Dimmendaal, G. J. 2001. Areal diffusion versus genetic inheritance: An African perspective. In A. Y. Aikhenvald \& R. M. W. Dixon (eds.), Areal diffusion and genetic inheritance, 358-392. Oxford: Oxford University Press.

Dorvlo, K. 2008. A grammar of Logba. Leiden: Leiden University Ph.D. Thesis.

Durie, M. 1997. Grammatical structures in verb serialization. In A. Alsina, J. Bresnan \& P. Sells (eds.), Complex predicates, 289-354. Stanford, CA: CSLI Publictaions.

Enfield, N. J. 2002. Cultural logic and syntactic productivity: Associated posture constructions in Lao. In N. J. Enfield (ed.), Ethnosyntax: Explorations in culture and grammar, 231-258. Oxford: Oxford University Press.

Enfield, N. J. 2007. A grammar of Lao. Berlin: Mouton de Gruyter. doi:10.1515/9783110207538 
Foley, W. A. 1997. Polysynthesis and complex verbs formation: The case of applicatives in Yimas. In A. Alsina, J. Bresnan \& P. Sells (eds.), Complex predicates, 355-395. Stanford, CA: Center for the Study of Language and Information, Stanford University.

Foley, W. A. 2010. Events and serial verb constructions. In M. Amberber, B. Baker \& M. Harvey (eds.), Complex predicates: Cross-linguistic perspectives on event structure, 79-109. Cambridge: Cambridge University Press. doi:10.1017/CBO9780511712234.005

Foley, W. A. \& M. Olson. 1985. Clausehood and verb serialization. In J. Nichols \& A. C. Woodbury (eds.), Grammar inside and outside the clause, 17-60. Cambridge: Cambridge University Press.

Foley, W. A. \& R. Van Valin. 1984. Functional syntax and universal grammar. Cambridge: Cambridge University Press.

Haspelmath, Martin 2016The Serial Verb Construction: Comparative Concept and CrossLinguistic Generalizations. Language and Linguistics 17(3): 291-319.

Heine, Bernd. 2008. From "Togorest" to GTM: Some reflections. Presented at the 2008 International Workshop on GTM Languages in Ho, Ghana.

Heine, B. 1968. Die Verbreitung und Gliederung der Togorestsprachen. Berlin: Reimer.

Hellan, L., D. Beermann \& E. S. Andenes. 2003. Towards a typology of serial verb constructions in Akan. In M. E. Kropp Dakubu \& E. K. Osam (eds.), Studies in the languages of the Volta basin, vol. 1, 87-110. Legon, Ghana: Linguistics Department, University of Ghana.

Himmelmann, N. P. 2013, May. Some observations on clausehood and event segmentation in Austronesian and Papuan Languages. Presented at the Sixth Austronesian and Papuan Languages and Linguistics conference, School of African and Asian Studies, London.

Jarkey, N. 1991. Serial verb constructions in White Hmong: A functional approach. Sydney: University of Sydney PhD Dissertation.

Kießling, R. 2011. Verbal serialisation in Isu (West-Ring) - a Grassfields language of Cameroon. Cologne, Germany: Rüdiger Köppe Verlag.

Kropp Dakubu, M. E. In press. Sub-classifying the languages of the lower Volta valley: Towards redefining Kwa. STUF - Language Typology and Universals.

Kropp Dakubu, M. E. \& K. C. Ford. 1988. The central-Togo languages. In M. E. Kropp Dakubu (ed.), The languages of Ghana, 119-154. London: Kegan Paul International.

Lewis, M. 1993. Verb serialization in Gen and the structure of events. Bloomington, IN: Indiana University Ph.D. dissertation.

Lord, C. 1993. Historical change in serial verb constructions. Amsterdam: John Benjamins. doi: $10.1075 /$ tsl.26

Maddieson, I. 1998. Collapsing vowel-harmony and doubly-articulated fricatives: Two myths about the Avatime phonological system. In I. Maddieson \& T. J. Hinnebusch (eds.), Language history and linguistic description in Africa, 155-166. Trenton, NJ/Asmara: Africa World Press.

Matthewson, L. 2004. On the methodology of semantic fieldwork. International Journal of American Linguistics 70(4). 369-415. doi:10.1086/429207

Osam, E. K. 1994. Aspects of Akan grammar: A functional perspective. Eugene, OR: University of Oregon Ph.D. dissertation.

Pawley, A. 2008. Compact versus narrative serial verb constructions in Kalam. In G. Senft (ed.), Serial verb constructions in Austronesian and Papuan languages, 171-202. Canberra: Pacific Linguistics.

Schuh, R. G. 1995. Avatime noun classes and concord. Studies in African Linguistics 24(2). 123149. 
Sebba, M. 1987. The syntax of serial verbs: An investigation into serialisation in Sranan and other languages. Amsterdam: John Benjamins. doi:10.1075/cll.2

Senft, G. 2008. Event conceptualisation and event report in serial verb constructions in Kilivila: Towards a new approach to research an old phenomenon. In G. Senft (ed.), Serial verb constructions in Austronesian and Papuan languages, 203-230. Canberra: Pacific Linguistics Publishers.

Seuren, P. 1991. The definition of serial verbs. In F. Byrne \& T. Huebner (eds.), Development and structures of Creole languages: Essays in honor of Derek Bickerton, 193-205. Amsterdam: John Benjamins. doi:10.1075/cll.9.21seu

Stewart, John M. 1989. Kwa. In John Bendor-Samuel (ed.), The Niger-Congo languages, 217-246. Lanham: University Press of America.

van Putten, S. 2009. Talking about motion in Avatime. Leiden: Leiden University Linguistics MPhil. thesis.

van Putten, S. 2014. Information structure in Avatime. Nijmegen: Radboud University Nijmegen Ph.D. thesis.

van Staden, M. \& G. Reesink. 2008. Serial verb constructions in a linguistic area. In G. Senft (ed.), Serial verb constructions in Austronesian and Papuan languages, 17-54. Canberra: Pacific Linguistics.

Van Valin, R. 2005. Exploring the syntax-semantics interface. Cambridge: Cambridge University Press. doi: $10.1017 / C B O 9780511610578$

Westermann, D. 1907. Grammatik der Ewe-Sprache. Berlin: Dietrich Reimer. doi:10.1515/9783111694191

Williamson, Kay \& Roger Blench. 2000. Niger-Congo. In Bernd Heine \& Derek Nurse (eds.), African languages: an introduction, 11-42. Cambridge: Cambridge University Press.

\section{Author's address}

Rebecca Defina

School of Languages and Linguistics

Babel (Building 139)

The University of Melbourne

Parkville 3010 VIC

Australia

Rebecca.Defina@unimelb.edu.au 